\title{
HUMANIZAM KAO STRUKTURA MISAONIH DOMETA U DJELU MILANA POLIĆA
}

\author{
Gordana Bosanac
}

Milan Polić spadao je u onu rijetku vrstu profesionalnih znalaca filozofije od kojih se svaki put, u svakoj prilici susreta na javnim skupovima, diskusijama i raspravama, moglo nešto novo naučiti, ili nešto od prije znano - bolje shvatiti. Onako usput, kao digresija, ti trenutačni uvidi kao lateralno zamjećivanje ili ukazivanje na posebna mjesta misaonih situacija u nekom filozofskom korpusu, događali su se sasvim spontano. U tokovima argumentacije, zapravo, uvijek postoje mjesta koja zahtijevaju svoje zasebno tumačenje, naročito u detaljima (kao npr. Kantovo razlikovanje male, sasvim neznatne prednosti kategorije vremena nad prostorom ili objašnjenje jedne veoma bitne distinkcije u poimanju rada: to jest djelatnosti kojom se zadovoljavaju ljudske potrebe, ali nikada neposredno, odmah i tu, nego radeći čovjek tek proizvodi sredstva njihova zadovoljenja, iz čega onda proizlaze sve one onto-povijesne posljedice otuđenja rada, itd.) što, uostalom, opravdava postojanje filozofskih učitelja, napokon filozofa kao stručnjaka koji se filozofijom profesionalno bave. Jer upravo oni koji filozofiju poznaju u detaljima, pozvani su da je meritorno tumače i objašnjavaju u svim slojevima njenih bujnih značenja.

Kolega Polić bio je jedan od takvih pouzdanih znalaca filozofije posjedujući tu osobinu strogosti ali i spontanosti ukazivanja na detalje filozofskih sadržaja, koja bi ponekad promakla i najboljima, a koji su ponekad toliko doprinosili njenu razumijevanju. Stoga sam svaki put s velikom pažnjom voljela slušati njegov istup, komentar, diskusiju ili izlaganje: uvijek je postojao neki detalj znanja kojega bi mi njegovo tumačenje otvorilo u većoj jasnoći, boljoj artikulaciji i uvidu na filozofijski način otkrivajući mi mogućnosti obrata nekog postava. To je dolazilo do izražaja i u njegovim pisanim tekstovima, kao primjerice u tekstu »Radnici, seljaci i poštena inteligencija« (Filozofska istraživanja 96 (1/2005), str. 183-187) koji logičko-kritički razara jedan ideološ- 
ki stereotip (a koji izvorno pripada Lenjinovu izrazu) koji se u okviru doktrinarne frazeologije često upotrebljavao i zlorabio. Dajući mu pripadajuće značenje u okviru marksističkog pojma klase, Polić ide i dalje, pokazujući u kojem smislu nije upitno i važno nekakvo klasno »poštenje«, nego klasna osviještenost društvenog položaja i mogućnost njihove promjene.

No, i u prilikama neposredne, javne filozofske diskusije Polić bi vrlo često odmah reagirao na izlaganje koje naoko ne sadrži nikakvu dilemu, nego opći neupitni stav na razini predodžbe koja je »uobičajena«, a zapravo pojmovno i moralno sumnjiva i neutemeljena i kao praksa i kao shvaćanje, kao što je to npr. medicinski tretman »anatomske greške« dvospolnosti. Medicina odmah, bez zadrške, a na bazi svog nekritičkog autoriteta, tu pojavu tretira »greškom « i sasvim neutemeljeno si uzima a priori pravo na kiruršku intervenciju kako bi anomaliju »ispravila«, uklonila kao slučajnu »grešku prirode«. Nakon što je u jednoj diskusiji bio izrečen ovaj stav, Polić isti čas reagira pitanjem: koje je moralno i logičko opravdanje takovog medicinskog stava, koji se legitimira samo svojim autoritetom? Odmah je njegova kritička intervencija pokazala kako smo glede takovih pitanja neosviješteni, koliko je kritička i moralna svijest tupa i »pospana« za detalje od presudne važnosti za ljudsko dostojanstvo. I ne samo to. Energično je postavio pitanje: odakle medicini autoritarno pravo moralnog i humanog prosuđivanja bioloških ili anatomskih pojava kao »normalnosti« ili »nenormalnosti«? Koja je osnova za njihovo isključivanje?

Polić je spadao u onu vrstu promicatelja filozofije koji su njene spoznaje mislili kao svoje najdublje uvjerenje, ali i živjeli u duhu njihovih saznanja. U njega je misaona razina bila neodvojiva od razine njegova djelovanja, a obje je nadahnjivao princip humaniteta kao misaoni i životni stav. Između njih nije postojala razlika: Polić je živio svoja uvjerenja i filozofiju, posebno onu marksističke provenijencije, koja je prožela njegovo djelo i njegov habitus načelima humaniteta.

Dva puta u životu imala sam priliku neposrednije se susresti s njegovim tekstovima i u javnosti prikazati njihovu vrijednost: prvi put davne 1978. godine, prilikom dodjele nagrade časopisa Žena, na natječaju koji je redakcija svake godine raspisivala na zadanu temu i dodjeljivala tri nagrade. Bila sam predsjednica žirija u Odboru za dodjelu te nagrade, pa me je na taj način, kao predsjedavajućom žirija, dopala čast uručiti prvu nagradu Milanu Poliću za najbolji esej na temu Ženstvenost, bitno pitanje budućnosti. 
Sasvim u duhu marksističkog shvaćanja društvene uvjetovanosti svih društvenih odnosa i pojavnosti, Polić postav svojih teza izvodi iz vidokruga ovog temeljnog uvida i samostalno zaključuje: budući da je čovjek suštinski društveno biće, $[\ldots]$ » »ni rasne, ni spolne, ni dobne niti bilo koje druge osobine same po sebi nisu dovoljne da odrede ljudsko biće, te su kao takve nedovoljne za određivanje ženstvenosti, kao ni muževnosti«. Kako je određenje čovjeka nedovršenost, i kako nema »konačnog « odgovora na pitanje što je čovjek, nema jednoznačnog, jedinstvenog odgovora na pitanje ženstvenosti kao ni muževnosti. Naprosto, treba najprije odgovoriti na pitanje što je čovjek i ljudskost, da bi se uopće uspostavila mogućnost propitivanja muškosti i ženskosti te njihova međuodnosa kao relacije razlike.

Time je sam okvir teme i njeno razrješenje postavljeno u onto-antropologijski okvir kojim se nadišla sfera nahođenja i mjerila javnog mišljenja, ili common sense, koje leži na relativnosti predrasuda i pounutrene ideologijske nabijeđenosti. Usput, treba primijetiti da je način obrade teme koju je u svom eseju poduzeo Polić za ono vrijeme bio veoma napredan i nov, iako kritički, izrijekom zaobilazi feminizam, koji je u nas još skoro sasvim nepoznat. Iako su njegovi eksplicitni stavovi o feminizmu veoma negativni, neke zaključne tvrdnje podudaraju se sa stavovima i shvaćanjima tzv. prvog i drugog vala feminizma. Naime, to je vrijeme tek upoznavanja ondašnje javnosti s pojavom feminizma, koji je veoma odbojno i provincijski primljen u našim sredinama, s neopravdanim predrasudama i temeljnim nepoznavanjem njegova sadržaja. Polić se, također, nije snašao u susretu s novom, snažnom svjetskom misli, pokretom i pojavom, iako i sam brani njegove osnovne teze i temelje, tako da, gledano $s$ današnje perspektive, on upada u proturječje: u tezama i svojim stanovištima brani ili zastupa isto ono za što se jednim svojim velikim dijelom zalaže feminizam: za humanističku perspektivu rodnih odnosa.

Druga prilika upoznavanja teksta Milana Polića pružila mi se kad sam zamoljena da na javnoj prezentaciji predstavim njegovu knjigu E(ro)tika i sloboda - odgoj na tragu Marxa (KruZak, Zagreb 1990.).

Etika je onaj diskurs Polićeve dominantne preokupacije u kojoj je njegova humanistička orijentacija došla do punog izražaja. Vezujući etički diskurs s diskursom odgoja, Polić u njihovu preplitanju nalazi njihov smisao. U nekoliko je značajnih tekstova kasnije produbio stavove iz te knjige, primjerice $u »$ Volja za vlast kao etika $\mathrm{i}$ demokraci- 
ja« (Filozofska istraživanja 92 (1/2004), str. 23-40) i »Vrijednosno i spoznajno u suvremenom odgoju« (Filozofska istraživanja 97 (2/2005), str. 373-387).

Diskurs odgoja u etičkom kontekstu u njegovim tekstovima dobiva novu dimenziju. Kritizirajući tradicionalni odgoj shvaćen kao manipulaciju, zastupa stav da »odgoj u suvremenom društvu mora biti zasnovan na stvaralaštvu«. Pri tome u analitiku odgojnog fenomena unosi jedan novi ali nužni naglasak, odnosno spoznajni uvid u prirodu znanja, a to su njegove vremenske dimenzije: prošlost i budućnost. Jer »ma koliko se domišljali o budućnosti, znanje se uvijek odnosi na prošlost«, iz čega proizlazi niz konsekvencija o kojima i etika i teorija obrazovanja moraju voditi računa.

A posebno mjesto u tome ima problem osobnosti i odgoja kao svrhe, problem manipulacije, odgoja i stvaralaštva itd.

U temelju svih prijepora kojima se bavio, Milan Polić oslanja se na humanističku osnovicu svojih filozofskih i etičkih uvida i spoznaja koje dubinski razrađuje i kritički razmatra kao mogućnosti koje se često previđaju i koje teško izlaze iz okvira ustajalog tradicionalizma na razini svjetonazora. A taj se prečesto otima za pretenziju onog mjesta kojeg zauzima kritička filozofska misao.

Kad s javne scene nestane ovakav podučavatelj, govornik i nenametnuti autoritet, filozofijski znalac i čovjek kao što je to bio Milan Polić, nastaje teško opisiva praznina. Osim sjećanja može je ispuniti stalno isčitavanje njegova teksta i promišljanje humaniteta kojim je zadužio svoje učenike, prijatelje i filozofiji naklonjenu publiku. 